\title{
Compared leaf anatomy of Nymphaea (Nymphaeaceae) species from Brazilian flood plain
}

\author{
Catian, $G .^{a,{ }^{*}}$ and Scremin-Dias, $E^{a, b}$ \\ ${ }^{a}$ Graduate Program in Plant Biology, Federal University of Mato Grosso do Sul, Cidade Universitária S/N, \\ CP 549, CEP 79070-900, Campo Grande, MS, Brazil \\ ${ }^{b}$ Department of Biology, Center for Biological Sciences and Health, Federal University of Mato Grosso do Sul, \\ Cidade Universitária S/N, CP 549, CEP 79070-900, Campo Grande, MS, Brazil \\ e-mail: gcatian@gmail.com
}

Received June 19, 2012 - Accepted October 31, 2012 - Distributed November 29, 2013

(With 3 figures)

\begin{abstract}
Nymphaea has seven species already catalogued in the flood prone areas of the Brazilian Pantanal. However, some species remain difficult to identify and descriptions of the anatomy of vegetative organs are an important tool for infrageneric separation to aid in group taxonomy. The species collected in the Pantanal and prepared according to the usual techniques for anatomical studies showed similar structural characteristics, and data on the arrangement of vascular bundles in the midrib and petiole, as well as the form and distribution of sclereids, were consistent. Nymphaea oxypetala stands out from the other evaluated species for having a greater number of differential characters, including angular collenchyma and the absence of bicollateral bundles in the petiole. Nymphaea lingulata stands out as the only species to feature bicollateral bundles in the leaf blade. The results, summarised in the dichotomous key, facilitate the identification of species that use the flower as the main differentiation, but are in a vegetative stage.
\end{abstract}

Keywords: anatomical differences, aquatic macrophytes, dichotomous key, Pantanal.

\section{(Anatomia comparativa da folha de espécies de Nymphaea (Nymphaeaceae) da planície de inundação brasileira)}

\section{Resumo}

Nymphaea tem sete espécies catalogadas nas áreas inundáveis do Pantanal brasileiro. No entanto, algumas espécies são de difícil identificação e descrições da anatomia dos órgãos vegetativos são uma ferramenta importante para a separação infragenérica para auxiliar na taxonomia do grupo. As espécies coletadas no Pantanal e preparadas de acordo com as técnicas usuais para estudos anatômicos mostraram as mesmas características estruturais, e os dados de arranjo dos feixes vasculares na nervura central e pecíolo, bem como a forma e distribuição de esclereides, foram consistentes. Nymphaea oxypetala se destaca das outras espécies avaliadas por ter um maior número de caracteres diferenciais, incluindo colênquima angular e ausência de feixes bicolaterais no pecíolo. Nymphaea lingulata se destaca como a única espécie que apresenta feixes bicolaterais no limbo. Os resultados, resumidos em uma chave dicotômica, facilitam a identificação de espécies que utilizam a flor como principal diferenciação quando se encontram em estágio vegetativo.

Palavras-chave: chave dicotômica, diferenças anatômicas, macrófitas aquáticas, Pantanal.

\section{Introduction}

The Nymphaeaceae features cosmopolitan distribution, comprising five genera and about 70 species (Löhne, Wiersema and Borsh, 2009), with the occurrence of seven species of Nymphaea L. described for the Brazilian Pantanal (Pott, 1998). This family, known in Brazil as "lagartixa", "camalote-da-meia-noite", "dama-da-noite", "batata-d'água" and "pata-de-boi", stands out for its wide distribution, represented by fixed floating species with floating leaves attached to a submerged organ, rizhome, by long petioles (Cronk and Fennessy, 2001).
Nymphaea amazonum Mart. \& Zucc., Nymphaea belophylla Trick., N. gardneriana Planch., $N$. jamesoniana Planch., $N$. lingulata Wiersema, $N$. oxypetala Planch. and $N$. prolifera Wiersema (Pott, 1998) all occur in the Brazilian Pantanal, and since they provide shelter to several organisms, they are important in the trophic chain of aquatic ecosystems (Irgang et al., 1984). According to Hamilton (unpublished results), this plant group promotes the self-purification of water by assimilating nutrients, retaining sediment, and eliminating pathogenic microorganisms. All species belong to the 
subgenus Hydrocallis (Neotropical nocturnal flowering), and are pollinated by Coleoptera from the genus Cyclocephala (Pott, 1998). According to Wiersema (1987), this subgenus is characterised by completely fused carpels, a swollen carpel appendage, and a usually tetramerous arrangement of perianth and outer stames, with or without acicular sclereids.

Investigations that characterise the morphology and chemical composition, as well as the anatomy of tissues and other secretory structures present in vegetative organs, are scarce for most Brazilian species, particularly aquatic macrophytes (Adamowicz, unpublished results). Knowledge of the structural peculiarities of this plant group has increased in recent years, especially with regard to adaptive characteristics related to the environment. Nevertheless, a large part of the generated data is not yet available in the literature. Therefore, this article describes the leaf anatomy of seven species of Nymphaea that occur in the Brazilian Pantanal, indicating consistent structures to facilitate the distinction among species, some very similar and difficult to identify the external morphology in the absence of flowers.

\section{Material and Methods}

\subsection{Study area}

The Pantanal, which features several different landscape units from the intensity and regularity of its flood pulse (Pozer and Nogueira, 2004), has an area of $140,000 \mathrm{~km}^{2}$, of which more than half is flooded during the rainy season by the main rivers and tributaries that drain into the plain (Pott and Pott, 1994). The climate in the region is sub-humid tropical - Aw (Koeppen, 1948) with dry winters and rainy summers. Mean annual precipitation ranges from 1,000 to $1,400 \mathrm{~mm}$, concentrated mainly between November and April (Soriano et al., 2001). Among the miscellaneous land formations in the region are bays and lagoons, either temporarily or permanently flooded, with aquatic plant species of various habits (Pott et al., 1989). According to Junk et al. (1989), floodplains are environments rich in organic matter and suspended sediment, resulting in slightly dark-coloured water.

\subsection{Samplings}

The fully developed leaves (leaf blade and petiole) of three individuals from different populations of $N$. amazonum, $N$. gardneriana, $N$. oxypetala and $N$. prolifera were collected during the rainy months in the areas influenced by the Miranda and Abobral Rivers and in natural and artificial lagoons (loan boxes with substrate for road construction) adjacent to the Pantanal Studies Base of the Federal University of Mato Grosso do Sul $\left(19^{\circ} 25^{\prime} 30.8^{\prime \prime} \mathrm{S}\right.$ and $\left.57^{\circ} 02^{\prime} 50.2^{\prime \prime} \mathrm{W}\right)$. The same method was adopted for $N$. lingulata at Rio Negro Farm $\left(19^{\circ} 34^{\prime} 15^{\prime \prime} \mathrm{S}\right.$ and $\left.56^{\circ} 14^{\prime} 43^{\prime \prime} \mathrm{W}\right)$. Because of restricted distribution and difficult localisation, samples of $N$. belophylla (CPAP 15553) and $N$. jamesoniana (CPAP
13347) were obtained from exsiccate in the Herbarium of the Federal University of Mato Grosso do Sul (CGMSUFMS). Voucher specimens were incorporated in the CGMS/UFMS herbarium for documentation: $N$. amazonum (CGMS 21898), N. gardneriana (CGMS 21899), $N$. oxypetala (CGMS 21901), $N$. prolifera (CGMS 21902), and N. lingulata (CGMS 21900).

\subsection{Histological preparation}

Fragments were removed from the margin $\left(1 \mathrm{~cm}^{2}\right)$ and middle portions of the blade $\left(1 \mathrm{~cm}^{2}\right)$ and petiole $(1 \mathrm{~cm})$, fixed in neutral buffered formalin (NBF) for $24 \mathrm{~h}$ (Seago et al., 2000), then washed in abundant running water and dehydrated in a graded ethylic series for preservation in $70 \%$ alcohol and later processing. The herborised material was rehydrated, boiled in water with drops of glycerin to expand the tissues, transferred to $70 \%$ ethanol (Kraus and Arduim, 1997), and stored for later sectioning.

In the process of creating permanent slides, the organ fragments were dehydrated up to $100 \%$ ethanol, blocked in historesin, sectioned at $5 \mu \mathrm{m}$-thick sections in a Leica rotary microtome, stained in toluidine blue $0.05 \% \mathrm{pH}$ 6.8, and set between the slide and coverslip (Kraus and Arduim, 1997).

In order to make semi-permanent slides, the sections, which were made by hand using steel blades, were cleaned in $20 \%$ sodium hypochlorite solution, washed in acidified water, stained with double colouration using $1 \%$ aqueous astra blue and $1 \%$ aqueous safranin in a 9:1 (v/v) ratio, according to techniques compiled by Kraus and Arduim (1997), mounted between the slide and coverslip with $50 \%$ glycerin, and sealed with clear nail polish.

\subsection{Analyses and illustrations}

The analyses and illustrations of materials were carried out using a photonic microscope attached to the image capture and photography system, and the corresponding micrometric scales were displayed. Diagrams of the material were also prepared with the aid of a photonic microscope attached to a camera lucida.

\section{Results}

The seven species have several anatomical characters in common; however, we did observe some consistent structures that make it possible to differentiate them (Table 1).

Leaf blade - The uniseriate epidermis - Ep - (Figure 1A) of all seven species features cells with sinuous anticlinal walls in paradermic section (Figure 1B - arrow) and thin cuticle $(\mathrm{Ct})$ evident in the adaxial surface epidermis - Epadax - (Figure 1C - arrow). All species feature epistomatic leaves with anomocytic stomata (St) set at the level of the epidermal cells, with evident stomatal crest - Stc - (Figure 1C) and substomatal chamber (Sc) extending down two or three layers of palisade parenchyma cells - Pp - (Figure 1A, C). 
Table 1 - Anatomical characters different obtained for the seven Nymphaea species of the Brazilian Pantanal. (N.A. Nymphaea amazonum, N.B. - N. belophylla, N.G. - N. gardneriana, N.J. - N. jamesoniana, N.L. - N. lingulata, N.O. - N . oxypetala, N.P. - N. prolifera); + (presence) - (absence) numbers (quantity).

\begin{tabular}{lccccccc}
\hline Characters & \multicolumn{7}{c}{ Species } \\
\cline { 2 - 7 } & N.A. & N.B. & N.G. & N.J. & N.L. & N.O. & N.P. \\
\hline Trichomes on petiole apex & + & - & - & - & - & - & - \\
Layer of chlorenchyma & 4 & 4 & 4 & 4 & 5 & 2 & 5 \\
Type of collenchyma & annular & annular & annular & annular & annular & angular & annular \\
Astrosclereids & + & + & + & + & + & - & + \\
Elongated sclereids & - & - & + & - & - & - & - \\
Tubular sclereids & - & - & + & - & - & - & - \\
Columnar sclereids & - & - & - & - & - & - & + \\
Bundles in midrib & 2 & 2 & 2 & 2 & 3 & 1 & 2 \\
Inverted phloem & - & 1 & - & 1 & 1 & - & - \\
Bicollateral bundles in the blade & - & - & - & - & 1 & - & - \\
Bicollateral bundles in the petiole & 2 & 2 & 2 & 1 & 6 & 0 & 2 \\
\hline
\end{tabular}

Hydropoten (Hd) occur in the epidermis of the abaxial surface - Epabax - (Figure 1A) in all species, along the leaf, including the midrib. They consist of three cells (Figure 1D - arrows): a basal cell, set at the level of the other epidermal cells; a medial cell; and an apical cell, deciduous, with a rounded extremity (Figure 1D - arrows).

Nymphaea amazonum features pluricellular, uniseriate, non-glandular trichomes (Figure 1E - arrow), evident both at the base of the leaf blade and petiole apex, and it is a consistent character which separates this species from the others.

The mesophyll is dorsiventral in all species (Figure1A), with palisade parenchyma (Pp) well differentiated, rich in chloroplasts that are distributed homogeneously and interrupted by the substomatal chambers. There are five chlorenchyma $(\mathrm{Pp})$ layers in $N$. lingulata and $N$. prolifera, two in $N$. oxypetala and four in the remaining species. The midrib features annular collenchyma $(\mathrm{Cl})$ subjacent to the abaxial surface epidermis (Ep) of the blade (Figure 1F) in N. amazonum, N. belophylla, $N$. gardneriana, $N$. jamesoniana, $N$. lingulata and $N$. prolifera, only differing in $N$. oxypetala (Figure 1G), which features angular collenchymas $(\mathrm{Cl})$.

The spongy tissue cells of this genus are arranged in regular formation, forming columns set between the epidermis of the lower surface of the leaf and the palisade $(\mathrm{Pp})$ layer, forming a polygonal chain with very large air chamber (As) meshes (Figure 1A, D), and in the midrib, there are different numbers of air spaces in all species.

Astrosclereids (arrows) are found in the aerenchyma (Figure 2A) in all species, except in $N$. oxypetala, and elongated sclereids (arrows) traversing the palisade parenchyma (Figure 2B) occur in $N$. amazonum, $N$. belophylla, $N$. gardneriana and $N$. jamesoniana. Robust and tubular sclereids (asterisks) are found in the palisade parenchyma of $N$. amazonum, $N$. belophylla, $N$. gardneriana and $N$. jamesoniana (Figure 2B). Columnar sclereids (arrows), which feature terminal branches setting parallel to the palisade parenchyma $(\mathrm{Pp})$ and reaching both surfaces of the leaf, are present in N. amazonum, $N$. belophylla, N. gardneriana and N. prolifera (Figure $2 \mathrm{C}$ ). Only $N$. oxypetala did not feature any type of sclereid in the blade.

The vascular bundles of the mesophyll are open collateral with bundle sheath rich in chloroplasts (Figure 2D - arrow) in all evaluated species. In the smaller bundles, the metaxylem $(\mathrm{Mx})$ has wide vessels interposed by small parenchyma cells (Figure 2E) in $N$. amazonum, $N$. gardneriana and N. prolifera. Protoxylem lacunae (P1), delimited by parenchyma cells $(\mathrm{Pa})$ arranged in regular formation (Figure 2E), are present in most large vascular units of the species, except in $N$. jamesoniana. Since leaves do not feature vessel elements, xylem is conducted by tracheids with spiral thickening. Phloem is well developed, but with reversed arrangement in N. belophylla and $N$. jamesoniana (Figure 2A), and $N$. lingulata (Figure $2 \mathrm{~F}$ ). Only $N$. lingulata presents bicollateral bundles in the midrib (Figure 2F).

The blade margin is patterned similarly for all evaluated species, with a layer of regular parenchyma (Rp), without supporting tissue, the absence of palisade parenchyma (Pp), and the presence of sclereids (S), vascular bundle $(\mathrm{Vb})$, stomata and hydropoten $(\mathrm{Hd})$. The margin has acute shape in $N$. amazonum, $N$. belophylla, $N$. gardneriana, $N$. jamesoniana, $N$. lingulata and $N$. prolifera (Figure $2 \mathrm{G}$ ), but it is rounded in $N$. oxypetala (Figure 2H).

Petiole - The petiole with uniseriate epidermis (Ep) and hydropoten (Hd) set along its length (Figure 3A) occurs in all species. Three layers of sub-epidermal annular collenchyma - Cl - (Figure 3B) are found in six of the spe- 

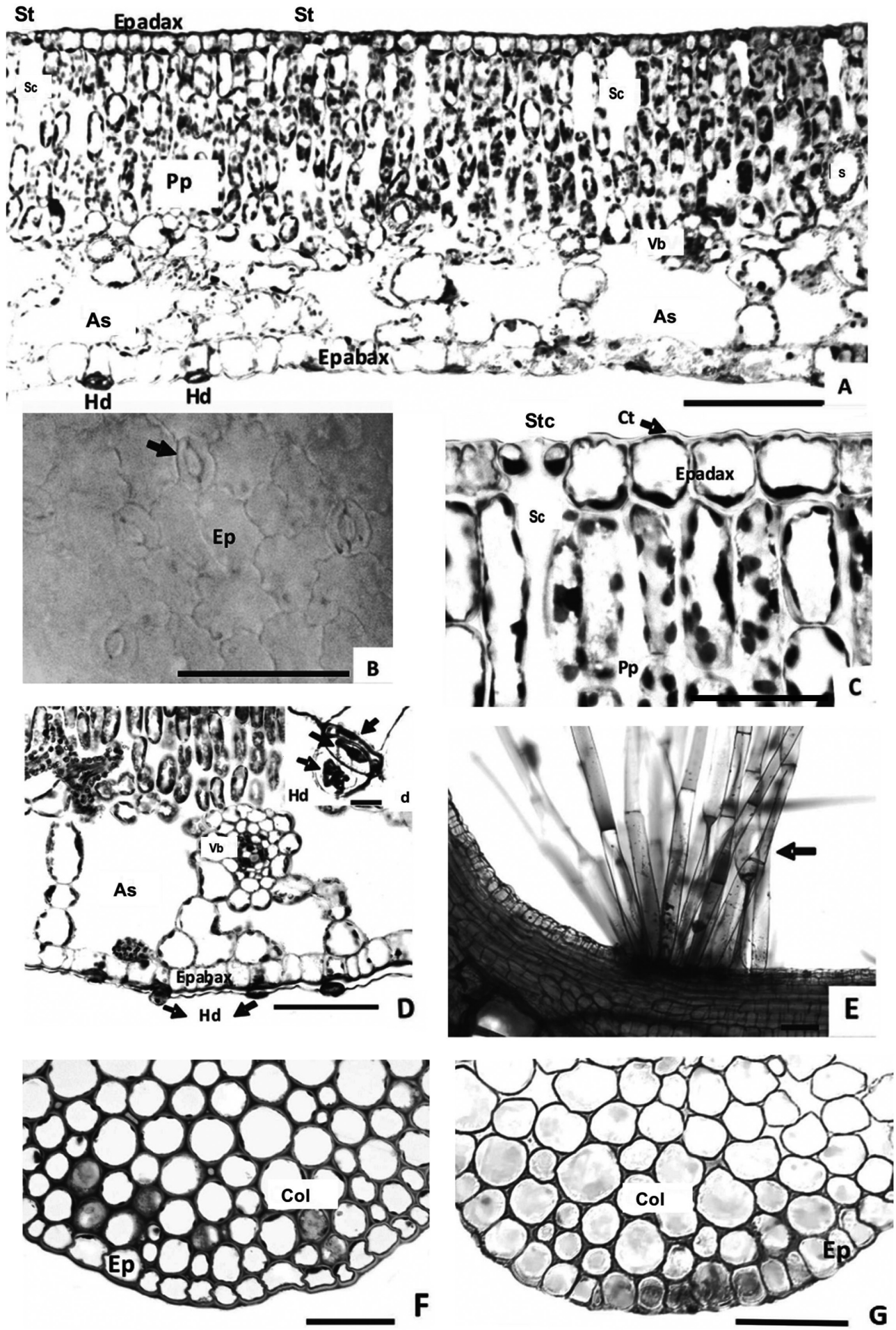

Figure 1 - Transverse and paradermal section of the blade of Nymphaea. Epidermis uniseriate and mesophyll dorsiventral with palisade parenchyma (A) in Nymphaea amazonum; epidermis sinuous and stomata anomocytic of N. gardneriana (B arrow); detail of cuticle (C - arrow), stomatic complex evidencing the crest and substomatal chamber (C) of N. amazonum; abaxial hydropoten (D - arrows) of N. amazonum; detail of hydropoten with three cells ( $\mathrm{d}$ - arrows); petiole with trichomes (E - arrow) in Nymphaea amazonum; annular collenchyma (F) of $N$. lingulata and angular collenchyma (G) of $N$. oxypetala. Substomatal chamber (Sc); Stomatal crest (Stc); Cuticle (Ct); Epidermis (Ep); Abaxial epidermis (Epiabax); Adaxial epidermis (Epiadax); Stoma (St); Vascular bundle (Vb); Hydropoten (Hd); Air space (As); Palisade parenchyma (Pp); Collenchyma (Col); Spongy parenchyma (Sp). (Figure scale: A, D, E, F, G = $100 \mu \mathrm{m}$; B, C = $50 \mu \mathrm{m}$ ). 

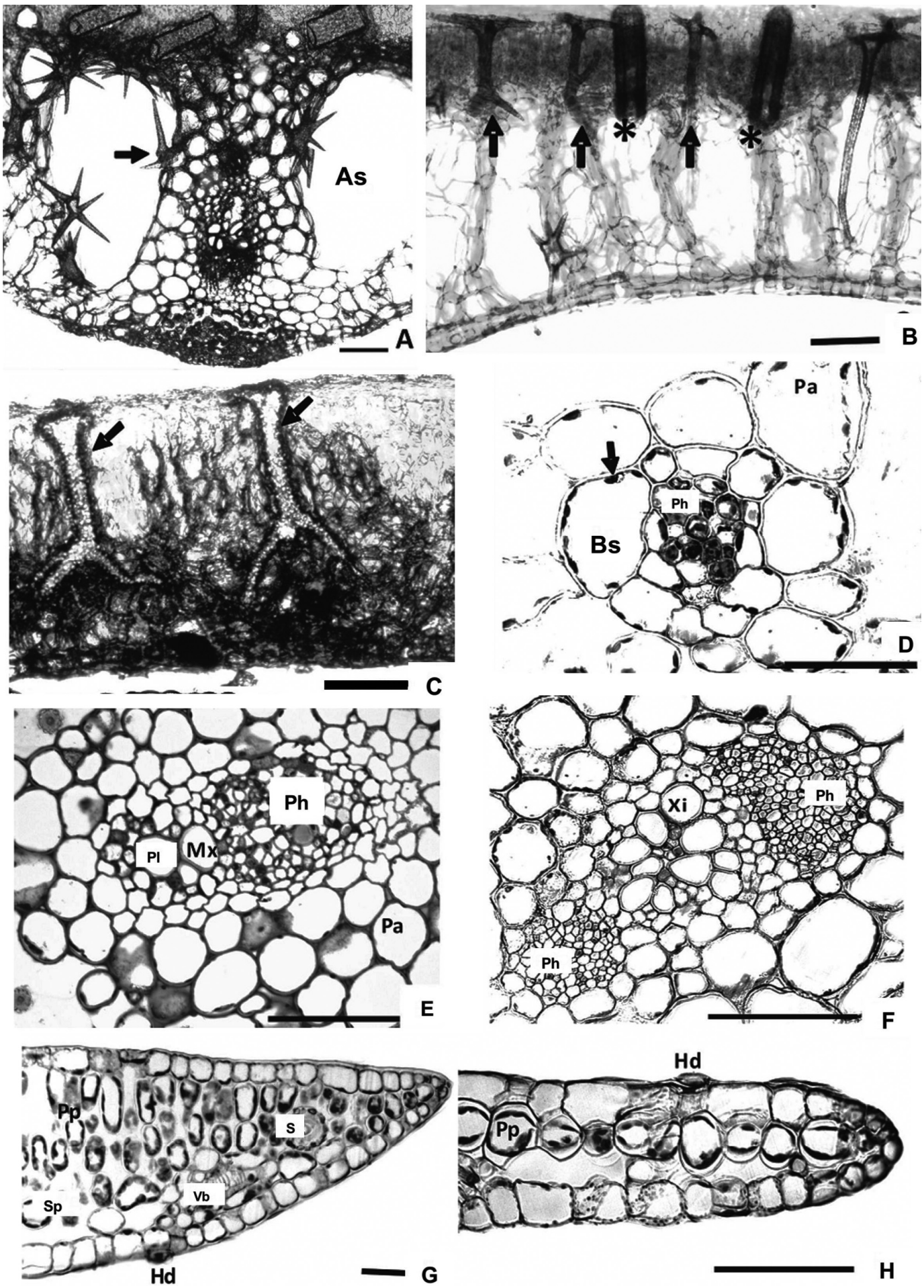

Figure 2 - Transverse sections of the blade of Nymphaea evidencing astrosclereids in the aerenchyma of Nymphaea jamesoniana (A - arrows); elongated sclereids in the palisade parenchyma of N. gardneriana (B - arrows) and tubular sclereids (B - asterisks); columnar sclereids in the mesophyll reaching the abaxial epidermis in N. prolifera (C - arrows); collateral vascular bundle with sheath with chloroplasts (arrow) in Nymphaea lingulata (D); bundle with protoxylem lacuna, metaxylem and phloem (E) in N. amazonum; bicollateral bundle of N. lingulata (F); fine blade margin (G) in N. amazonum and rounded in N. oxypetala $(\mathrm{H})$. Bundle sheath (Bs); Sclereid (S); Vascular bundle (Vb); Phloem (Ph); Hydropoten (Hd); Air space (As); Protoxylem lacuna ( $\mathrm{Pl})$; Metaxylem $(\mathrm{Mx})$; Parenchyma $(\mathrm{Pa})$; Spongy parenchyma (Sp); Palisade parenchyma (Pp); Xylem (Xi). (Figure Scale: A, B, C, E, F = $100 \mu \mathrm{m} ; \mathrm{D}=50 \mu \mathrm{m}$ ). 

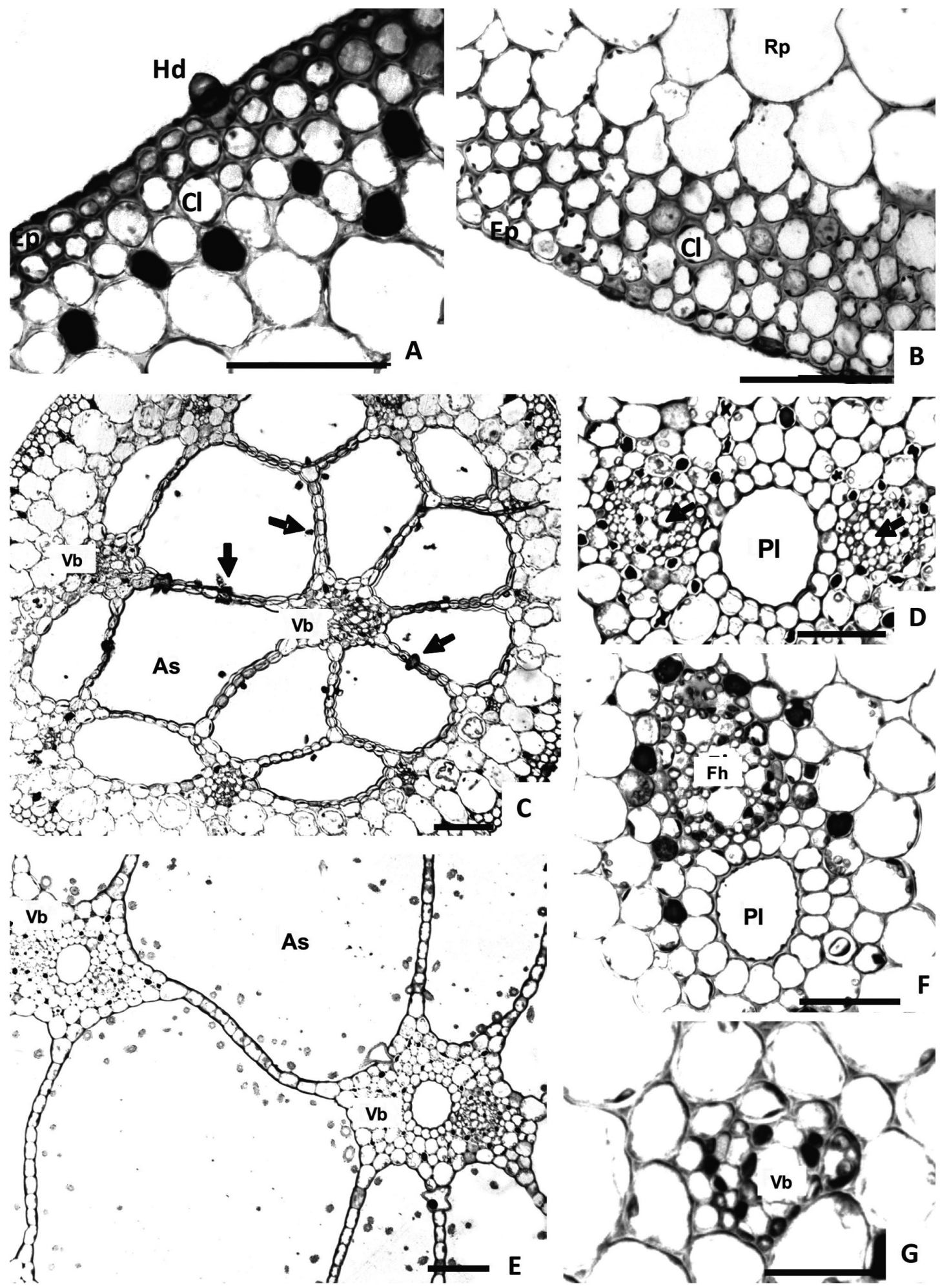

Figure 3 - Transverse section of the petiole of Nymphaea. Uniseriate epidermis and angular collenchyma (A) in N. oxypetala; annular collenchyma in $N$. amazonum (B); aerenchyma with sclereids (C - arrows) in the petiole of $N$. oxypetala; bicollateral vascular bundle (arrows) with protoxylem lacuna (D) in N. amazonum; two opposite bicollateral bundles (E) in $N$. gardneriana; collateral bundle with protoxylem lacuna (F) in $N$. amazonum; collateral vascular bundle with sheath with chloroplasts in N. amazonum (G). Collenchyma (Cl); Epidermis (Ep); Vascular bundle (Vb); Phloem (Ph); Hydropoten (Hd); Air space (As); Protoxylem lacuna (Pl); Regular parenchyma (Rp); Xylem (Xi). (Figure Scale: A, B, C, D, E, F, G = 100 m). 
cies, except $N$. oxypetala, which features an angular-type layer (Figure 3A).

For all seven species, there is a similarity in the anatomical pattern of the midrib mesophyll formed by a parenchymal cortex with vascular bundles arranged in regular formation, with the region inside the cortex consisting of regular aerenchyma (As) with sclereids ( $\mathrm{S}$ - arrows) projected on the inside of the lacunae (Figure 3C).

Bicollateral bundles (Figure 3D) occur in six species, except $N$. oxypetala. There are differences in the number of bundles when comparing the species. N. amazonum, $N$. gardneriana and $N$. prolifera have two central bicollateral bundles in opposing positions, with a large central protoxylem lacuna (Figure 3E). Six bicollateral bundles with lacuna (As) are found in $N$. lingulata, two in $N$. belophylla, and one in $N$. jamesoniana. In terms of collateral bundles with lacuna (Figure 3F), $N$. amazonum, $N$. lingulata and $N$. jamesoniana feature seven. $N$. gardneriana has six, $N$. prolifera has ten, and three are found in $N$. belophylla and $N$. oxypetala. Six collateral bundles without lacuna (Figure 3G) are present in $N$. amazonum, seven in $N$. lingulata, ten in $N$. belophylla, and four in $N$. oxypetala.

The anatomical differences in the leaves were sufficiently consistent to distinguish the taxa and make it possible to devise an identification key based on the foliar characters easiest to recognise.

\subsection{Leaf anatomy identification key for Nymphaea species occurring in the Pantanal}

1 Trichomes at petiole apex. N. amazonum

1 'Absence of trichomes at petiole apex

2 Angular collenchyma, two layers of palisade parenchyma in mesophyll, one vascular bundle in middle vein of the blade, collateral bundle in petiole N. oxypetala

2' Annular collenchyma, more than two layers of palisade parenchyma in mesophyll, more than two vascular bundles in middle vein of the blade, bicollateral bundle in petiole.

3 Bicollateral bundle in blade, three vascular bundles in middle vein, six bicollateral vascular bundles in petiole. ..N. lingulata

3' Collateral bundle in blade, fewer than three vascular bundles in middle vein, and fewer than six bicollateral vascular bundles in petiole.

$$
\begin{aligned}
& 4 \text { Reversed phloem........................................ } \\
& 5 \text { Petiole with one bicollateral bundle } \\
& \text {..............................................mesoniana } \\
& 5 \text {, Petiole with two bicollateral bundles }
\end{aligned}
$$

4' Non-reversed phloem.

6 Four layers of palisade parenchyma in mesophyll....................... gardneriana

6' Five layers of palisade parenchyma in mesophyll............................... prolifera

\section{Discussion}

Leaf blade - All species featured uniseriate epidermis on both surfaces of the leaf blade, a characteristic cited by Adamowicz (unpublished results) for $N$. amazonum. The presence of an evident thin cuticle helps repel water from the surface of floating leaves (Gonzalez, 2002), as the stomata are arranged on the adaxial surface, and the presence of water on that surface would obstruct these structures. Fahn (1990) states that stomata help absorb nutrients and exchange gas, but they do not have a protective function against transpiration in these plants, as aquatic species do not face desiccation. Nevertheless, maintaining an intense hydric flow is important for the absorption of nutrients diluted in the water environment (Scremin-Dias, 2009).

The presence of anomocytic stomata on the adaxial epidermis corroborates the description by Mauseth (1988) and Gonzalez (2002) for the genus and that by Solereder (1908) for Nymphaeaceae. Sculthorpe (1967) affirms that stomata are restricted to the adaxial surface of the blade, allowing for water vapor loss and easier absorption of oxygen and carbon dioxide. This author also observed ample substomatal chambers for the genus, corroborating our data for the species we evaluated.

The hydropoten in adult leaves illustrated by Gonzalez (2002) and Metcalfe and Chalk (1979) for Nymphaea species have three cells, which were confirmed in the evaluated species. The abscission of the apical cell of hydropoten in adult leaves of the individuals evaluated corroborates data cited by Carpenter (2006) for Nymphaeaceae. That author denominates hydropoten as unicellular or multicellular trichomes and, based on analyses of evolutionary characters, it is affirmed that this trichome is a synapomorphy for Nymphaeales. Hydropoten are cited by Sculthorpe (1967) and Lavid et al. (2001) as structures that facilitate the transport of water and ions into the plant, subsequently translocated through the vascular system in the mesophyll.

Non-glandular trichomes observed on the apex of the petiole in $N$. amazonum were also cited by Wiersema (1987) for the species. According to Pott (1998), this ring of trichomes is an important character in identifying this species, and, out of the seven species evaluated in this work, it is present only in N. amazonum.

The dorsiventral anatomy of the blade was observed to have a polygonal arrangement of spongy tissue consisting of typical aerenchyma, and the adaxial region of the mesophyll was occupied by homogeneous palisade parenchyma interrupted by ample substomatal chambers. These observations corroborate the description by Gonzalez (2002) for this order. As observed in the majority of species we evaluated, the presence of annular collenchymas with cell walls spaced more uniformly, leaving from the circular cell lumen, is corroborated by Sculthorpe's description (1967) for Nymphaea. The presence of angular collenchyma in $N$. oxypetala is a characteristic different from the description for the genus, separating it from the others. 
According to Coan et al. (2002), the presence of highly compartmentalised aerenchyma represents an important adaptation, as it facilitates the storage of a minimum quantity of oxygen required in aquatic environments and makes it possible to transport oxygen from the leaves to the root. The large amount of sclereids inside the lacunae offers resistance, as these species do not have supporting tissues (Sculthorpe, 1967).

Astrosclereids in the aerenchyma were reported by Conard (1905) as the most common type in the species of the genus. Sculthorpe (1967) also describes star-shaped sclereids that project into the lacunae of the spongy tissue in members of the family Nymphaeaceae. The interpreted function of these structures is to provide support for the palisade and spongy tissue of the leaves (Conard, 1905). The several different shapes of sclereids in the mesophyll observed for the studied species of Nymphaea were also described by Wiersema (1987) for the leaves of the subgenus Hydrocallis.

Elongated sclereids found in the mesophyll of some species, according to Evert (2006), consist of immature cells; upon the development of the organ, they will reach both surfaces of the epidermis. However, the completely expanded leaves of Nymphaea evaluated in this study indicate that the cell types observed had already completed ontogenesis and were distributed among the parenchymae, not reaching both surfaces of the leaf. The type of tubular sclereid described in this work for N. amazonum, $N$. belophylla, $N$. gardneriana and $N$. jamesoniana had already been reported by Wiersema (1987) as acicular sclereids for the genus, except for $N$. amazonum subsp. amazonum. Columnar sclereids, also evidenced in some species, were cited by Sculthorpe (1967) as common for the genus.

These specialised cells provide mechanical support and appear late during organ ontogenesis, when tissues increase in volume (Sculthorpe, 1967). The absence of these structures in $N$. oxypetala, also confirmed by Wiersema (1987), may be related to the reduced size of its floating leaves or the reduced thickness of the blade of its submersed leaves, as sclereids provide mechanical support to leaves.

For Sculthorpe (1967), the ample protoxylem lacunae observed in the vascular bundles of the seven species may represent the only structure that transports water for many aquatic species. According to that author, several families of aquatic plants do not form metaxylem, but all evaluated Nymphaea species have metaxylem elements, although the number of cells varies. Only tracheids occur in the metaxylem, corroborating the description by Cheadle (1942) for the family, which indicates an absence of vessel elements for the group.

The existence of reversed vascular bundles in the leaves of several hydrophytes led Arber (1918) to conclude that there is a "pseudoblade" in leaves with that characteristic, which results from the flattening of the petiole, resembling a phyllode. Although this characteristic is illustrated in some members of Alismataceae and Pontederiaceae, it has not been cited for Nymphaeaceae.
Despite the basal position of Nymphaeaceae, it is believed that the "pseudoblade" does not occur because the species in that family feature phloem with reversed position only in the midrib, not in the intervein regions, as occurs with monocotyledons. Arber considers that only the occurrence of such bundles outside these midribs, and it, may be considered pseudo-lamina. So, we believe inverted bundles observed in $N$. lingulata, $N$. belophylla and $N$. jamesoniana midrib not be construed phyllodic cases, because this type of anatomical structure here observed might equally well be taken to indicate that the organ showing is similar the midrib region of a Eudicotyledonous leaf, which may also have inverted bundles in midribs.

The composition of the leaf margin described for the species has already been reported by Fahn (1990) for aquatic plants, in general, and for $N$. amazonum in a work by Gonzalez (2002). Although the structure is similar in all the species evaluated, the shape of the margin was consistent enough to separate $N$. oxypetala from the others.

Petiole - The petiole having a uniseriate epidermis with hydropoten, as observed in all species, corroborates the description by Gonzalez (2002) for this order. The cortex parenchyma, air spaces, and sub-epidermal collenchyma observed in the petiole of Nymphaea were cited by Gonzalez (2002) for the genus. According to Sculthorpe (1967), the peripheral cortex of the petiole is comprised of parenchyma cells, or collenchyma, arranged in a compact formation, and aerenchyma and vascular bundles occur in the central cortex, a structure similar to that described in this work.

Conard (1905) notes the variable pattern of air spaces in different Nymphaea species, but our find aerenchyma reticulate in all petioles. The reticulate pattern of the air spaces was observed by Scremin-Dias (unpublished results) in the petiole of Ludwigia sedoides (Humb. \& Bonpl.) Hara and by Bona and Alquini (1995 a,b) in the petiole of Hydrocleys nymphoides (Humb. \& Bonpl. ex Willd.) Buchenau and Limnobium laevigatum (Humb. \& Bonpl. ex Willd.) Heine, indicating that this arrangement is common in the aerenchyma of aquatic plants.

With the exception of $N$. oxypetala, the six species have a bicollateral bundle, a characteristic cited by Sculthorpe (1967) for the petiole of this genus. The separate and reduced bundles, with various arrangements among the species of the genus, are cited by Metcalfe and Chalk (1979) as being opposite to each another with the xylem facing one another, similar to the pattern observed for the petioles evaluated in our work.

Anatomically, the species described herein feature different taxonomic values, which are consistent for taxa distinction. Plants that were objects of specific studies and which feature only vegetative portions and are morphologically similar may, in light of our study, be separated by anatomical analysis of their leaves. 


\section{Acknowledgments}

We thank Vali Joana Pott for plant identification; the National Counsel of Technological and Scientific Development $(\mathrm{CNPq})$; and the Office of the Research and Graduate Provost (PROPP) at the Universidade Federal de Mato Grosso do Sul.

\section{References}

ADAMOWICZ, RAG., 2007. Estrutura, desenvolvimento, histoquímica e atividade antioxidante dos órgãos vegetativos de Nymphaea amazonum Mart \& Zucc. (Nymphaeaceae) procedente do Pantanal/MS, Brasil. Campo Grande: Universidade Federal de Mato Grosso do Sul. 62 p. Tese de Doutorado.

ARBER, A., 1918. The phyllode theory of the monocotyledonous leaf, with especial reference to anatomical evidence. Annals of botany, vol. 32, p. 465-501.

BONA, C. and ALQUIMI, Y., 1995a. Alguns aspectos estruturais da folha de Hydrocleis nymphoides (Humb. \& Bonpl. ex Willd.) Buchenau (Limnocharitaceae). Archives of biology and technology, vol. 38, p. 869-877.

BONA, C. and ALQUIMI, Y., 1995b. Alguns aspectos estruturais da folha de Limnobium laevigatum (Humb. \& Bonpl. ex Willd.) Heine (Hydrocharitaceae). Archives of biology and technology, vol. 38, p. 1045-1052.

CARPENTER, KJ., 2006. Specialized strutures in the leaf epidermis of Basal Angiosperms: morphology, distribution and homology. American Journal of Botany, vol. 93, no. 5, p. 665-681

CHEADLE, VI., 1942. The occurrence and types of vessels in various organs of the plant in the Monocotyledoneae. American Journal of Botany, vol. 29, p. 441-450.

COAN, AI., SCATENA, VL. and GIULIETTI, AM., 2002. Anatomia de algumas espécies aquáticas de Eriocaulaceae brasileiras. Acta Botanica Brasilica, vol. 16, no. 4, p. 371-384.

CONARD, HS., 1905. A Monograph of the Genus Nymphaea. Washington: Carnegie Institution. $279 \mathrm{p}$.

CRONK, JK. and FENNESSY, MS., 2001. Wetland plants: biology and ecology. Washington, New York: Lewis Publishers. $462 \mathrm{p}$.

EVERT, RF., 2006. Esau's Plant Anatomy, Meristems, Cells, and Tissues of the Plant Body: their Structure, Function, and Development. New Jersey: John Wiley \& Sons. 601 p.

FAHN, A., 1990. Plant Anatomy. Oxford: Pergamon Press. 588

GONZALEZ, AM., 2002. Anatomia del vástago em especies selectas de plantas hidrófilas. In ARBO, MM. and TRESSENS, SG. (Eds.). Flora del Iberá. Corrientes: EUDENE. $613 \mathrm{p}$.

HAMILTON, SK., 1993. Características limnológicas de importância para as plantas aquáticas no Pantanal. In Resumos do II Encontro de Botânicos do Centro Oeste. Brasília: SBB; Corumbá: UFMS/CEUC. 14 p.
IRGANG, BE., PEDRALLI, E. and WAECHTER, JI., 1984. Macrófitos aquáticos da Estação Ecológica do Taim, Rio Grande do Sul, Brasil. Roessléria, vol. 6, p. 395-404.

JUNK, WJ., BAYLEY, PB. and SPARKS, RE., 1989. The flood pulse concept in river floodplains. Canadian Special Publication of Fisheries and Aquatic Sciences, vol. 106, p. 110-127.

KOEPPEN, W., 1948. Climatologia: com un estudio de los climas de la Terra. Ciudad de México: FCE. 87 p.

KRAUS, JE. and ARDUIM, M., 1997. Manual básico de métodos em morfologia vegetal. Universidade Federal Rural do Rio de Janeiro: Seropédica. 198 p.

LAVID, N., BARKAY, Z. and TEL-OR, E., 2001. Accumulation of heavy metals in epidermal glands of the waterlily (Nymphaeaceae). Planta, vol. 212, p. 313-322.

LOHNE, C., WIERSEMA, JH. and BORSCH, T., 2009. The unusualOndinea, actually just another Australian water-lily of Nymphaea subg. Anecphya (Nymphaeaceae). Willdenowia, vol. 39 , no. 1 , p. 55-58.

MAUSETH, JD., 1988. Plant Anatomy. Menlo Park: Benjamin/Cummings. $560 \mathrm{p}$.

METCALF, CR. and CHALK, L., 1979. Anatomy of the Dicotyledons. vol. I. Oxford: Clarendon Press. 276 p.

POTT, VJ., BUENO, NC., PEREIRA, RAC., SALIS, SM. and VIEIRA, NL., 1989. Distribuição de macrófitas aquáticas numa lagoa na fazenda Nhumirim, Nhecolândia, Pantanal, MS. Acta Botanica Brasilica, vol. 3, no. 2, p. 153168.

POTT, A. and POTT, VJ., 1994. Plantas do Pantanal. Brasília: Embrapa. $320 \mathrm{p}$.

POTT, VJ., 1998. A família Nymphaeaceae no Pantanal, Mato Grosso e Mato Grosso do Sul, Brasil. Acta Botanica Brasilica, vol. 12, no. 2, p. 183-194.

POZER, CG. and NOGUEIRA, F., 2004. Pastagens nativas inundáveis da região norte do Pantanal de Mato Grosso: variações de biomassa e de produtividade primária. Brazilian Journal of Biology, vol. 64, no. 4, p. 859-866.

SCREMIN-DIAS, E., 1992. Morfoanatomia dos órgãos vegetativos de Ludwigia sedoides (Humb. \& Bonpl.) Hara (Onagraceae) ocorrente no Pantanal Sul-Mato-Grossense. (unpublished results). Curitiba: Universidade Federal do Paraná. Dissertação de mestrado.

SCREMIN-DIAS, E., 2009. Tropical aquatic Plants: morphoanatomical adaptations. In Del-Claro, K. and Rico-Gray (Eds.). Encyclopedia of Tropical Biology and Conservation Management. Paris: UNESCO/EOLSS. p. 84-132.

SCULTHORPE, CD., 1967. The Biology of aquatic vascular plants. London: Eduard Arnold. $610 \mathrm{p}$.

SEAGO-JR, JL., PETERSON, CA., KINSLEY, LJ. and BRODERICK, J. 2000. Development and structure of the root cortex in Caltha palustris L. and Nymphaea odorata Ait. Annals of Botany, v. 86, p. 631-640.

SOLEREDER, H., 1908. Sistematic Anatomy of the dicotyledons. vol. I. Oxford: Clarendon Press. 643 p.

SORIANO, BMA., CLARKE, RT. and CATELLA, AC., 2001. Evolução da erosividade das cheias na bacia do rio Taquari. Boletim de Pesquisa, vol. 25, p. 18.

WIERSEMA, JH., 1987. A monograph of Nymphaea subgenus Hydrocallis (Nymphaeaceae). Systematic Botany Monographs, vol. 16, p. 101. 